\author{
Maria Zadencka (iD https://orcid.org/0000-0001-8998-4269 \\ Stockholm University \\ maria.zadencka@slav.su.se
}

\title{
Polski reportaż w Szwecji
}

\section{Polish Reportage in Sweden}

Abstract: The article discusses three doctoral theses (of Anna Jungstrand, Anita Pluwak and Cecilia Aare) defended at Swedish universities that focused on the genre of reportage and included among other things the analyses of texts by Polish authors - Hanna Krall, Ryszard Kapuściński, Wojciech Tochman and Jacek Hugo-Bader. The article describes the theoretical starting points of these research works and the methods of identifying the characteristic features of the Polish authors' writing style: the creation of "credibility" of the literary reportage from the perspective of multilevel narrative (Jungstrand), the "meeting situation" between readers and characters of the reportage (Aare) and the interplay of temporal perspective with the "technique of pressure" if a reportage text is to be read from the perspective of Peter Brooks' theory of melodrama (Pluwak). Conclusions of the researchers were juxtaposed with the voices of critics (Peter England, Joan Tiberg), commented upon was also the Maciej Zaremba's thesis about the role of communist censorship in formation of writing style of Polish reporters that appeared in the preface to the anthology of Swedish translations of Polish reportages (2006) that was also repeated by Jungstrand and Aare.

Keywords: literary reportage, focalisation, "technique of pressure”, melodrama, Anna Jungstrand, Cecilia Aare, Anita Pluwak, Maciej Zaremba, communist censorship

Streszczenie: Artykuł omawia trzy prace doktorskie obronione na uczelniach szwedzkich (Anny Jungstrand, Anity Pluwak i Cecilii Aare) poświęcone gatunkowi reportażu i zawierające między innymi analizy tekstów polskich autorów - Hanny Krall, Ryszarda Kapuścińskiego, Wojciecha Tochmana i Jacka Hugo-Badera. Opisane zostały teoretyczne punkty wyjścia tych prac badawczych oraz sposoby ujmowania charakterystycznych cech warsztatu polskich pisarzy: jak budowana jest na poziomie wielopoziomowej narracji „wiarygodność” reportażu literackiego (Jungstrand), „sytuacja spotkania” między czytelnikami i bohaterami reportażu (Aare) oraz jak perspektywa czasowa współgra z technique of pressure, jeśli odczytywać tekst reportażu w perspektywie teorii „melodramatyczności” Petera Brooksa (Pluwak). Ustalenia badaczek zestawione zostały z głosami krytyków (Peter Englund, Joar Tiberg), skomentowana też została powtórzona przez Jungstrand i Aare teza Macieja Zaremby ze wstępu do antologii szwedzkich tłumaczeń polskich reportaży (2006) o roli komunistycznej cenzury w formowaniu warsztatu polskich reportażystów.

Słowa kluczowe: reportaż literacki, fokalizacja, technique of pressure, melodramatyczność, Anna Jungstrand, Cecilia Aare, Anita Pluwak, Maciej Zaremba, cenzura komunistyczna 
Rok 2003 wydawał się rokiem epokowym dla polskiego reportażu w Szwecji. Tematem targów książkowych w Göteborgu w roku 2003 była Polska, a polski reportaż miał na nich mocną reprezentację. Do Göteborga przyjechali Ryszard Kapuściński i Hanna Krall. Przed targami pojawiły się wznowienia, w wydaniach kieszonkowych, trzech książek Kapuścińskiego, które wcześniej ukazały się w wydawnictwie Boniers Alba: Heban (szw. „Ebenholts”), Imperium („Imperiet”) i Wojna futbolowa („Futbolskriget”) Kapuścińskiego oraz tłumaczenie najnowszej książki Hanny Krall To ty jesteś Daniel („Det är du som är Daniel”). Ważnym wydarzeniem było wydanie pod redakcją Macieja Zaremby zbioru reportaży pisanych przez dziennikarzy z kręgu „Gazety Wyborczej”, Ouvertyr till livet („Uwertura do życia”, 2003)1. W antologii znalazły się w utwory Wojciecha Tochmana, Jacka Hugo-Badera, Lidii Ostałowskiej, Wojciecha Jagielskiego, Mariusza Szczygła, Włodzimierza Nowaka, Ireny Linkiewicz ${ }^{2}$. Dla czytelników szwedzkich były to przeważnie nowe nazwiska. Można powiedzieć, że w pewnym sensie przedmowa Zaremby do tego tomu ukształtowała sposób widzenia reportażu polskiego po przemianach 1989 roku.

Przepowiadano dobre czasy dla polskiej literatury i polskiego reportażu w Szwecji ${ }^{3}$.Z perspektywy czasu wydaje się jednak, że niewiele się zmieniło. W dalszym ciągu wydawane były kolejne książki Kapuścińskiego i Krall. Z nazwisk reprezentowanych w antologii jedynie Biata goraczka Hugo-Badera doczekała się tłumaczenia na język szwedzkí . Ponadto ukazało się thumaczenie $M y z J e d w a b-$ nego Anny Bikont ${ }^{5}$ oraz tłumaczenie fragmentu książki Małgorzaty Szejnert $U s y$ pać góry ${ }^{6}$. Kapuściński i Krall utrzymywali i utrzymują nadal swoją pozycję ikon gatunku reportażowego i ich książki cieszą się zainteresowaniem recenzentów.

Pierwsze trzy książki Kapuścińskiego odkrył dla wydawnictwa Alba ${ }^{7} \mathrm{Da}-$ niel Hjort - zostały przełożone z języka angielskiego przez Britt Arenander: $\mathrm{Ce}$ sarz, Szachinszach, Jeszcze dzień życia. Wszystkie późniejsze tytuły tłumaczył Anders Bodegård, który otrzymał kontrakt z Albert Bonniers Förlag9? Pierwszą

1 Ouvertyr till livet („Uwertura do życia”), wybór, przedm. M. Zaremba, Köping 2003.

2 Tytuł antologii pochodzi z reportażu Linkiewicz wchodzącego w skład książki. Tłumaczenia poszczególnych tekstów w tomie: Rita i Erik Tornborg, Maciej Zaremba, Lisa Mendoza Åsberg, Anders Bodegård, Tomas Håkansson.

${ }^{3}$ L. Schmidt, Polsk litteratur är på gång i Sverige („Pora na literaturę polską w Szwecji”), „Svensk Bokhandel”, 27.09.2003, dostęp: 5.05.2021.

${ }_{4}^{4}$ J. Hugo-Bader, Vit feber, thum. L. Mendoza Åsberg, Stockholm 2015.

5 A. Bikont, Vi frän Jedwabne, tłum. I. Grönberg. Stockholm 2014.

6 M. Szejnert, Miss Boyd reser till Polesien, tłum. T. Håkanson, „Ord \& Bild” 2017, nr 2-3.

Alba była oddziałem wydawnictwa Bonnier i ostatecznie po kilku przekształceniach weszła do Albert Bonniers Förlag w roku 1998.

8 R. Kapuściński, Kejsaren: en envåldshärskares fal, Stockholm 1985; tenże, Shahernas shah, Stockholm 1986; tenże, En dag till att leva, Stockholm 1987.

9 L. Schmidt, dz. cyt.; R. Kapuściński, Imperiet, Stockholm 1993; tenże, Fotbollskriget, Stockholm 1998; tenże, Ebenholz, Stockholm 2000; tenże, På resa med Herodotos, Stockholm 2006; tenże, Reporters självporträtt, Stockholm 2009. 
przetłumaczoną książką Hanny Krall był reportaż o Marku Edelmanie Zdążý́ przed Panem Bogiem (Hinna före Herren Gud, 1982) ${ }^{10}$. Po jedenastoletniej przerwie została odkryta na nowo. Jej tłumaczami byli Lennart Ilke, Anders Bodegård, a od roku 1997 Julian Birbrajer. Przekłady były publikowane w wydawnictwach Norstedts i Ordfront, przede wszystkim Symposion oraz Ersatz (po roku 2017). W sumie ukazało się ponad dziesięć tytułów, a cztery z nich po roku 2017.

\section{Korzenie polskiej szkoły reportażu a cenzura}

Wydaje się jednak, iż wydawnicze wydarzenia roku 2003 sprawiły, że choć od tego czasu nie zmienił się znacznie horyzont nazwisk polskich reporterów znanych czytelnikom szwedzkim, to jednak zaczęto widzieć reportaż polski jako „fenomen”, który z czasem stał się jednym z punktów odniesienia i zaczął dostarczać przykładów do teoretycznego opisu gatunku zwanego „reportażem literackim”.

W moim artykule chciałam naszkicować właśnie ten szczególny typ recepcji polskiego reportażu w Szwecji, który nazwać można byłoby recepcją profesjonalną czy „lekturą znawców”"

Podstawowym materiałem, na którym chcę się oprzeć, są trzy prace doktorskie powstałe w okresie 2013-2021: Anny Jungstrand, Det litterära med reportaget. Om litteraritet som journalistisk strategi och etik („Literackość reportażu. Literackość jako wyraz dziennikarskiej strategii i etyki”, Stockholm 2013) Anity Pluwak, Ambiguous Endeavours. The Evolution of the Melodramatic Mode in Polish Holocaust Narratives from Hanna Krall to "Aftermath” ("Wieloznaczne starania. Ewolucja melodramatycznej konwencji w polskich narracjach dotyczących Holocaustu od Hanny Krall do Poktosia", Lund 2015) oraz Cecilii Aare, Reportaget som berättelse. En narratologisk undersökning av reportagegenren („Reportaż jako opowiadanie. Narratologiczne studium gatunku reportażu”, Stockholm 2021).

Jak widzą i szczegółowo problematyzują polski reportaż młodzi literaturoznawcy w Szwecji?

We wstępie do Ouvertyr till livet Maciej Zaremba napisał, że „najwyższa jakość polskich reportaży (...) jest, paradoksalnie, konsekwencją cenzury, która przez przeszło czterdzieści lat przemieniła dziennikarstwo w zajęcie dla dworaków i agentów policji”

- i wyjaśniał:

Generalnie rzecz biorąc, istniały dwie dziedziny, w jakich ambitni dziennikarze mogli konkurować ze sobą - jedna to zabieganie o względy władzy, druga - przechytrzanie cenzury. Wiadomości dziennikarskie nie nadawały się do tego typu sztuczek, a tym bardziej reportaż, trzymający się niskich sfer rzeczywistości. Jeśli tylko

${ }^{10}$ H. Krall, Hinna före Herren Gud, thum. L. Ilke, Stockholm 1982.

${ }^{11}$ J. Sławiński, O dzisiejszych normach czytania (znawców), „Teksty” 1974, nr 3. 
przywierał do ziemi, zajmował się jakąś marginesową nieprawidłowością w zapomnianej prowincjonalnej dziurze i rezygnował z uogólniających wniosków, uznany zostawał za nieszkodliwy dla komunizmu, mógł ujrzeć światło dzienne - i przechodzi1 $^{12}$.

Zaremba opisuje skrótowo, jakie cechy stylu dziennikarskiego utrwaliła cenzura w reportażu, zarówno w praktyce jego twórców, jak i w świadomości odbiorców: specjalną wrażliwość na detal, symboliczno-realistyczny język, który pozwalał omijać cenzurę, ale był rozumiany przez czytelników „tak jak być powinien”, budowanie tekstów na wzór sztuk teatralnych, gdzie sens ukazywał się pomiędzy autentycznymi scenami i replikami. Cenzura, „nie zdając sobie z tego sprawy, ożeniła reportaż z literaturą i teatrem"13. Zacytowany został Adam Michnik, który podkreślał, że w reportażu „szuka tego, co inne, pojedyncze i konkretne a nie tego co uogólniające" ${ }^{\prime \prime}$.

Ta skrótowa diagnoza specyficznych cech polskiego reportażu była zgrabnym ujęciem retorycznym, które prawdopodobnie miało jednocześnie przybliżyć szwedzkiej publiczności warunki funkcjonowania literatury w czasie panowania komunizmu i scharakteryzować cechy reportażu literackiego, specjalnie wyostrzone i rozwinięte w polskich tekstach, jako mówienie „nie wprost”. Ten skrót, który sugeruje ogólnie niechętną systemowi pozycję reportażowej literatury, mówi jednakże w pewnym sensie też o tym, co z czasem zostało słusznie sproblematyzowane w niektórych szwedzkich reakcjach na polskie reportaże, do czego jeszcze powrócę. Chodzi o brak pewnego typu wrażliwości, pewnego typu odpowiedzialności i o specyficzny sposób generalizowania - zastrzeżenia wyrażane jednak zawsze z podziwem dla językowego i literackiego warsztatu, który robi wrażenie. Wyjaśnienie dotyczące roli cenzury w formowaniu stylu polskiej szkoły reportażu ze wstępu Macieja Zaremby zostanie powtórzone w pracach młodszych literaturoznawców - tym razem dosłownie i w pewnym uproszczeniu - jako jedyna i sobie tylko właściwa droga rozwoju polskiego reportażu, w izolacji od świata $\mathrm{i}$ innych literatur zatem - oraz bez uwzględnienia jego starszej tradycji. Nie jest to zarzut, ale stwierdzenie faktu.

\section{O „literackości reportażu”}

W roku 2008 przetoczyła się w prasie dyskusja na temat odgraniczania prozy niefikcjonalnej od literatury pięknej (sakprosa - skönliteratur) w związku z ukazaniem się książki norweskiego profesora badań prozy niefikcjonalnej Uniwersytetu

${ }^{12}$ M. Zaremba, [Wstęp] [w:] Ouvertyr till livet, dz. cyt., s. 8. O ile nie zaznaczono inaczej, tłumaczenia cytatów własne - M.Z.

13 Tamże.

14 Tamże, s. 9. 
w Oslo, Johanna L. Tønnessona Hva er sakprosa („Czym jest proza niefikcjonalna”, 2008). Jego szwedzki kolega z tego samego uniwersytetu, Arne Melberg, zwracał uwagę, że linia wyraźnie rozgraniczająca teksty fikcjonalne i literaturę faktu jest ideą modernizmu (tu powołuje się na tradycję Szkłowskiego) i że taki punkt widzenia należy raczej do literaturoznawczej przeszłości. Pisał też, że w literaturze szwedzkiej istniała od lat sześćdziesiątych mocna tradycja dokumentaryzmu „antymodernistycznego", to jest utworów o ambicjach literackich, wprowadzających fikcję i osobisty ton, a jednocześnie mocno osadzonych w rzeczywistości (Göran Palm, Per Olov Enqvuist, Sven Lindqvist) - tradycja, która jest kontynuowana do dzis ${ }^{15}$.

Mniej więcej od czasu tej dyskusji datuje się wzrost zainteresowania literaturoznawców badaniami prozy dokumentarnej. Od kilku lat planuje się ustanowienie profesury prozy niefikcjonalnej ${ }^{16}$. W roku 2013 został obroniony na Uniwersytecie w Sztokholmie pierwszy doktorat na temat teorii reportażu literackiego, wspomniana już praca Anny Jungstrand Det litterära med reportaget.

Jungstrand charakteryzuje „literackość reportażu” jako, po pierwsze, dziennikarską strategię opisywania rzeczywistości i, po drugie, jako aspekt reportażu bezpośrednio związany z wymiarem etycznym. Książka podzielona jest na część teoretyczną i część zawierającą sześć szczegółowych analiz konkretnych reportaży, w tym dwa rozdziały poświęcone są odpowiednio Ryszardowi Kapuścińskiemu i Hannie Krall ${ }^{17}$.

Podstawowym założeniem pracy jest, że jeśli bierze się za punkt wyjścia strukturę tekstu, nie ma możliwości, by ocenić, czy tekst jest prawdziwy na poziomie ontologicznym. Jungstrand posługuje się pojęciem "narratywizacja” wyprowadzonym $\mathrm{z}$ teorii fikcjonalizacji Wolfganga Isera, gdzie fikcja jest ogniwem między tym, co realne, a imaginacją - siłą, która stapia ze sobą pozatekstualne realności i wewnątrztekstualne wyobrażenia o nich. „W ten sposób fikcja czyni rzeczywistość bardziej rzeczywistą i bardziej stabilną" ${ }^{18}$. Drogą do badania wiarygodności tekstu zatem, twierdzi Jungstrand, jest przede wszystkim analiza subiektywnych narracyjnych perspektyw - głosów narratora, ich wzajemnego oddziaływania i przede wszystkim wzajemnego podważania „dysonansu”, a także sposobów „dysonansowych” fokalizacji - oddawania głosu postaciom. Pojęcie „dysonansu” i koncept rozdziału perspektyw narracji na

15 A. Melberg, Ny litteratur passar inte in i gamla genrer, „Svenska Dagbladet” [„Under strecket"], 28.08.2008.

${ }^{16}$ Gotowość wyraziło kierownictwo Linnéuniversitetet, który wspólnie ze Związkiem Literatów szuka jej sponsorów: https://forfattarforbundet.se/forfattarforbundet-och-linneuniversitetet-i-unikt-samarbete-kring-professur-i-sakprosa/, dostęp: 15.05.2021.

17 Cztery pozostałe rozdziały: Djuna Barnes - Vagaries Malicieux, Truman Capote - In Cold Blood, Sven Lindqvist - Kina nu, Joan Didion - Slouching towards Bethlehem.

18 A. Jungstrand, Det litterära med reportaget, Ellerströms akademiska 41, Lund 2013, s. 29, http://su.diva-portal.org/smash/get/diva2:651856/FULLTEXT01.pdf, dostęp: 1.04.2021; za: W. Iser, The Fictive and The Imaginary: Charting Literary Anthropology (1991), London 1993, s. 3. 
„reportera przeżywającego” i „reportera opowiadającego” przejmuje Jungstrand z prac Dorrit Cohn ${ }^{19}$.

Za pomocą środków literackich (na przykład intertekstualnych nawiązań) tworzona jest i jednocześnie interpretowana sytuacja „spotkania”, kluczowa dla tekstu reportażu. Oprócz badania subiektywnych perspektyw „narratywizacji” ważne są tu środki językowe (na przykład wprowadzanie rytmu, metafor) i metajęzykowe (na przykład komentarze zamieszczone we wstępie, tytuły rozdziałów), poprzez które deklaruje się dokumentalność i wiarygodność tekstu. Koncepcję etyczności reportażu wywiedziona została z filozofii Emmanuela Lévinasa i odnosi się do ujęcia subiektywności. Podmiot tworzy się w spotkaniu z drugim, które ma charakter spotkania w mowie, jest zawsze asymetryczne, nietrwałe, w ruchu i podtrzymujące dystans. Etyczność oddziela Jungstrand od reporterskiej moralności, politycznej czy społecznej agendy: chodzi o spotkanie „bez nadziei na zrozumienie, wyjaśnienie czy zmianę"20.

W badaniach swoich Jungstrand koncentruje się na reportażach lat sześćdziesiątych i siedemdziesiątych jako na tych, które wyznaczają szczyt pewnych tendencji rozwoju gatunku i jednocześnie tworzą ramy dla reportażu współczesnego. Oprócz reportażu anglojęzycznego, przede wszystkim amerykańskiego New Journalism, oraz szwedzkiego dziennikarstwa i jego fali dokumentarnej „dla zrównoważenia” czerpie przykłady z reportaży polskich. Tezą Jungstrand jest, że o ile szwedzki reportaż w tych latach ulegał wpływowi New Journalism, drogi rozwoju polskiej sztuki reportażu były inne, a do ukształtowania jej cech charakterystycznych przyczyniła się przede wszystkim cenzura panująca w krajach komunistycznych ${ }^{21}$.

Osobne rozdziały pracy poświęcone są analizie książki Jeszcze dzień życia Ryszarda Kapuścińskiego oraz Powieści dla Hollywoodu Hanny Krall z tomu Hipnoza (1989). W opracowaniu przywołane są oprócz tego reportaże Jacka Hugo-Badera oraz Wojciecha Tochmana ze wspomnianego wyżej tomu Ouvertyr till livet.

\section{Ryszard Kapuściński - „nieosobista osobowość”}

Jeszcze dzień życia jest relacją z Angoli, z czasu tuż po wycofaniu się Portugalii $\mathrm{z}$ roli państwa kolonialnego w roku 1975 i wybuchu wojny domowej. Po pierwsze, książka Kapuścińskiego w pracy Jungstrand jest okazją do dyskutowania pytania o wiarygodność reportażu - o relację między faktami a fikcją. Zarzuty stawiane Kapuścińskiemu dotyczące błędów i zmieniania faktów - Jungstrand przytacza

19 D. Cohn, Transparent Minds: Narrative Modes for Presenting Consciousness in Fiction, Princeton-New Jersey 1978.

${ }^{20}$ A. Jungstrand, dz. cyt., s. 274 .

${ }^{21}$ Tamże, s. 21, 34. 
recenzję Johna Ryle'a z Szachinszacha ${ }^{22}$ (2001) oraz powołuje się na biografię Domosławskiego $(2012)^{23}$ - przeciwstawione są tu argumentom w jego obronie, które generalnie odpowiadają „postmodernistycznemu rozchwianiu pojęcia prawdy". Jungstrand przytacza je za Soenke Zehle (2011), który pisze, że fikcja literacka wprowadzona w materię reportażu wzmacnia poczucie obecności i uczestnictwa, że pozwala reporterowi zaznaczyć swoje własne stanowisko w danej sprawie i że w tak rozumianym dokumencie trzeba zawsze rozdzielać ontologię od epistemologii ${ }^{24}$.

Po drugie, analiza reportażu Kapuścińskiego w tej pracy aktualizuje pytania o paradoks reprezentacji - o to, jak można pisać możliwie osobiście, formować perspektywę subiektywnego podmiotu, i jednocześnie unikać niebezpieczeństwa angażowania się w opisywaną sytuację, utrzymać obiektywizm, którego wymaga gatunek reportażu. Tutaj autorka przygląda się, jak Kapuściński posługuje się perspektywami narratora „przeżywającego" i „opisującego”, by stwierdzić, że są one wprawdzie oddzielone, ale nie są wykorzystane do budowania wiarygodności. Wiarygodność jest budowana u Kapuścińskiego w inny sposób. Jungstrand przytacza cytaty, które świadczą o tym, że wysuwanie na plan pierwszy własnej osoby, podkreślanie roli macho-reportera i dziennikarza-bohatera w samokreacjach, chociaż pojawiają się u Kapuścińskiego także w innych kontekstach, to w tomie Jeszcze dzień życia odgrywają szczególną rolę. Ich przesadne wyeksponowanie mówi o stanie depresyjnego chaosu, na który tak właśnie reaguje przeżywający (i piszący) reporter, odsyła do sytuacji, w jakiej reporter się znajduje (i którą opisuje). Odpowiedniość tę podsumowuje słowo klucz - confusao:

confusao oznacza zamieszanie, bałagan, stan anarchii i nieładu. Confusao to taka sytuacja, którą wywołali ludzie, ale w jej przebiegu utracili nad nią kontrolę i panowanie, sami stając się ofiarami confusao. Jest jakiś fatalizm w confusao. Człowiek chce coś zrobić, a wszystko rozłazi mu się w rękach, chce coś zdziałać, a jakaś siła paraliżuje go ${ }^{25}$.

Wspomniane tu, ważne dla pracy Jungstrand, rozróżnienie reportera „przeżywającego" i „opisującego" działa w ten sposób, że tworzy dystans czasowy, który bywa wykorzystany w reportażu, by uzupełniać fakty i przemyślenia. Powstający wówczas „dysonans” otwiera przed czytelnikiem możliwość własnej interpretacji i wzmacnia wiarygodność tekstu. Jungstrand twierdzi, że w wypadku tekstów Kapuścińskiego te dwie role niezbyt często wprowadzają tego typu dysonans. Dzieje się tak ze względu na fakt, że Kapuściński ciągle komentuje siebie

22 J. Ryle, At Play in the Bush of Ghosts: Tropical Baroque, African Reality and the Work of Ryszard Kapuścinsski, „Times Literary Supplement”, 17.06.2001.

23 A. Domosławski, Ryszard Kapuściński: A Life, tłum. A. Lloyd-Jones, London 2012.

${ }^{24}$ A. Jungstrand, dz. cyt., s. 173; za: S. Zehle, Ryszard Kapuścinski and The Borders of Documentarism: Toward Exposure without Assumption [w:] Literary Journalism Across The Globe: Journalistic Traditions and Transnational Influences, red. J.S. Bak, Bill Reynolds, Massachusetts 2011, s. 280.

25 Tamże, s. 178; R. Kapuściński, Jeszcze dzień życia, Warszawa 2008, s. 114. 
samego i swoje pisanie jako „osobiste”, nie ufając innym metodom wprowadzania informacji na temat „pisania” i „przeżywania”, na przykład właśnie wykorzystaniu „dystansu” czasowego. W ten sposób jego osobiste pisanie traci aurę osobistego pisania - Jungstrand nazywa to „nieosobistą osobowością” (den opersonliga personligheten $)^{26}$. Zadaje pytanie, skąd ta niechęć do używania perspektyw, jeśli użyte wzmacniałyby pożądany przez Kapuścińskiego efekt subiektywnego przeżywania i pisania. Stawia tezę, że tekst potrzebuje jak najsilniejszego, wiarygodnego ,ja” po to, by wypowiadać generalizujące sądy (na przykład na temat afrykańskich kobiet czy Afrykańczyków), które niemal rytmicznie pojawiają się w reportażu Kapuścińskiego. Autorka intepretuje je jako całkowicie świadomą przesadę - wobec faktu, że równolegle istnieje wiele wypowiedzi, które podkreślają poświęcenie i zaangażowane przeciw przesądom egzotyzującym Afrykę. W logice tekstu wypowiadanie generalizacji to także sposób na zwalczenie własnego stanu rozbicia i strachu, confusão.

Jungstrand analizuje też sposób opisywania przez Kapuścińskiego „Innego”. Stwierdza, że nie zostaje stworzona sytuacja spotkania, właśnie z powodu wszechobecnych generalizacji i stałego podkreślania subiektywności, tak obcesowego, że właściwie tę sytuację unieważnia. Tekst zatem, w jej przekonaniu, nie sprawdza się pod względem etyki takiej, jakiej sens nakreśliła wcześniej. Uważa też, że Kapuściński, który faktycznie powoływał się na Lévinasa w swoich wykładach, nie interpretuje go dokładnie, że „Inni” oznaczają dla niego ludzi z pozaeuropejskich kultur, których spotykał w swych podróżach - i że spotkaniu z Innym nadaje on sens „wzajemności”, a nie, jak Lévinas, „asymetryczności”.

Jednak, Jungstrand uważa, że ostentacyjne generalizacje wydają się mieć swój sens wobec ruchu, jaki widoczny jest w tym z gruntu modernistycznym tekście reportażu, przejętym ideą subiektywnej relacji reportera, zawieszającego ostentacyjnie wymaganie obiektywizmu. Tekst staje się przez to nie odejściem, ale pertraktacją z wymaganiami obiektywizmu, jako że generalizacje ze swej natury są częścią wizji świata budowanej na obiektywizmie.

O problemach poruszonych w pracy Jungstrand pisze innym językiem i w innym kontekście historyk Peter Englund ${ }^{27}$. Jego wypowiedź o Kapuścińskim (opublikowana na blogu) jest recenzją biografii napisanej przez Artura Domosławskiego Ryszard Kapuścinski: A Life (2016).

Englund pisze o sławie Kapuścińskiego i uznaniu dla jego literackich reportaży, a także komentuje fakt odkrywania błędów, konfabulacji i przemilczeń. Konfabulacje i błędy - stwierdza - nie wpływały może zasadniczo na przekaz jego utworów, choć Kapuściński rzeczywiście nie był pedantem w kwestii ustaleń historycznych i sprawdzania faktów.

26 A. Jungstrand, dz. cyt., s. 179.

27 Peter Englund, historyk, do roku 2018 członek Akademii Szwedzkiej pełniący funkcję jej statego sekretarza w latach 2009-2015. Por. Blog Petera Englunda [On Ryszard Kapuścinski], https:// peterenglundsnyawebb.wordpress.com/2016/08/22/on-ryszard-kapuscinski/, dostęp: 12.06.2021. 
Kapuściński był w równej mierze skomplikowany, jak utalentowany, wieloznaczny i chętny do przesady. Englund wskazuje na pewne cechy autokreacji Kapuścińskiego, a przede wszystkim, że szczycił się, iż potrafi „rozmawiać wszędzie i ze wszystkimi", że łatwo przyjmował za dobrą monetę barowe plotki, szeptane pogłoski, jeśli tylko zgadzały się z „esencją" - było to jedno z jego słów kluczy. U Jungstrand ta cecha opisana jest jako predylekcja do uogólnień i generalizacji, do „ogarnięcia świata, który się rozpada”. Dla Englunda „esencja” jest wyrazem ideologicznej wizji świata. Kapuściński był „wyznawcą” - pisze - i jako wyznawca angażował się w swoje podróże i akcje podobnie jak w czasach stalinowskich angażował się w partyjną działalność. Lubił dramatyzować siebie i swój „katastroficzny" stan umysłu, był rewolucjonistą i romantykiem, ale zdaje się, że przeoczył narastającą rewolucję we własnym kraju - stwierdza Englund w tym wypadku niezbyt zgodnie z biografią Kapuścińskiego, który był w Stoczni Gdańskiej w czasie strajków 1980 roku.

Englund uważa, że w obliczu talentu Kapuścińskiego można byłoby traktować jego konfabulacje, z zakłopotaniem wprawdzie, ale mimo wszystko, jako „ludzką, arcyludzką" słabość, gdyby nie okoliczność, że zapowiadały one pewien „wzór” znacznie poważniejszy. Englund ma na myśli to, że Kapuściński nigdy nie sprostował faktów nieprawdziwych, które z czasem składały się na tworzenie jego medialnej postaci (jak znajomość z Che Guevarą), a także to, iż po przełomie 1989 roku nigdy nie skomentował swojej długoletniej przynależności do partii ani nie wyjaśnił swojej współpracy z wywiadem i służbami bezpieczeństwa (Englund przyznaje jednak, że Kapuściński nie ujawniał podczas tej współpracy rzeczy istotnych). Na te fakty właśnie nakłada się problem nigdy nie sprostowanych błędów w jego książkach, sam w sobie być może mniejszej wagi, ale tu ukazujący się jako „wierzchołek góry lodowej”.

Biografia Kapuścińskiego i jego autokreacje dają Englundowi okazję do wypowiedzenia się na temat samego gatunku:

Reportaż literacki jest prawdopodobnie bardziej problemem postawy niż gatunku. W każdym razie literackość w reportażu literackim nie zwalnia z ustalania faktów, które się podaje. Nie jest też możliwe, w moim przekonaniu, by widzieć reportaż jako rozsuwalną skalę, gdzie można powoli wprowadzać krople fikcji do tekstu faktograficznego aż do momentu, kiedy mikstura przetransponuje się w całkowitą fikcję. Nie, kiedy raz element fikcji zostanie wprowadzony do tekstu, wszystko zmienia się natychmiast w fikcję, bardzo możliwe, że w fikcję, która bardzo mocno przypomina świat rzeczywisty, ale mimo wszystko, fikcję ${ }^{28}$.

Książka Domosławskiego, pisze Englund, przypomina, że odsłaniamy się także w naszych ucieczkach i konfabulacjach i że część prawdziwej historii o rzeczywistości 
mieści się w deformacji rzeczywistości. „Mimo wszystko talent Kapuścińskiego jest bezsporny. W dalszym ciągu uwielbiam jego książki"29.

\section{Hanna Krall - „metareportaż” i „melodramatyczność”}

Powieść dla Hollywoodu Hanny Krall nazwana jest w pracy Jungstrand „metareportażem na każdym swym poziomie", z nieskończoną wariacją subiektywnych strategii. Jungstrand za jedną z najbardziej charakterystycznych cech pisarstwa Hanny Krall uważa grę na poziomie metafikcji, która buduje tkankę reportażu i jednocześnie, na wielu płaszczyznach, powtarza motyw niemożliwości opowiadania.

Postać, wokół której ogniskuje się reportaż Powieść dla Hollywoodu, przedstawiona jest jako Izolda R. Reporterskie „ja” jest pisarką, która ma zawrzeć wspomnienia Izoldy R. w formie obszernej powieści, ze wszystkimi stereotypowymi cechami hollywoodzkiego filmu. Jungstrand traktuje tekst Krall jako reportaż, w którego centrum stoi wielokrotnie sproblematyzowane pytanie o reprezentację (reprezentację w ustnym opowiadaniu, w samym reportażu, w pisanej powieści, reprezentację w szerszym kontekście literatury Holokaustu, w zestawieniu powieści i reportażu) i o zrozumienie jej zmiennej natury - jak również pytanie o „spotkanie” i jego asymetryczny układ, czyli też w końcu pytanie o etykę. Zarówno dystans opowiadającej bohaterki do własnej przeszłości, jak i działanie wyobraźni reporterki oraz jej z kolei dystans do implikowanego autora powodują szereg napięć i dysonansów w obrębie tekstu i przekształcają się wedle własnej logiki. Wywołują obrazy, które prowadzą do powolnej przemiany, ruchu w kierunku zrozumienia - na przykład funkcję taką pełni przywoływany obraz przezroczystej zasłony, która zdaje się oddzielać opowiadającą i słuchającą od symultanicznie obecnych wydarzeń, o których rozmawiają. Podobną rolę odgrywa poszukiwanie przez reporterkę detalu, który ma wzmocnić działanie jej wyobraźni i pomóc w pisaniu - w przytoczonym przykładzie chodzi o szczegóły dotyczące gazet wspomnianych przez Izoldę R., które, poznane, powodują wstrząs i zrozumienie. W opowiadaniu, które - jak się okazuje - nie może być ukończone, w szeregu asymetrycznych sytuacji w kontakcie między Izoldą R. a pisarką/ reporterką powstaje poczucie zyskanej podmiotowości. Tak, zdaniem Jungstrand, tworzy się warstwa etyczna tego reportażu.

Choć praca Jungstrand zyskała uznanie recenzentów, podnoszących oryginalność opisu warsztatu metodologicznego i teoretycznego oraz precyzję analizy wybranych reportaży, właśnie ten moment „etyczny” spotkał się z krytyką. Zdaniem komentatorów posłużenie się elementami filozofii Emmanuela Lévinasa nie wydaje się sprawdzać w zastosowaniu do utworów dziennikarskich,

29 Englund wspomina, że Ryszard Kapuściński był wielokrotnie wymieniany w dyskusjach o przyznaniu Nagrody Nobla (tamże). 
które trudno sobie wyobrazić jako pisane bez „nadziei na zrozumienie, wyjaśnienie czy zmianę"30, czyli całkowicie bez śladu ideologii. „Tak rozumiane tworzenie się podmiotowości w spotkaniu z drugim jako »Innym « pozostaje pustym gestem" 31 .

Interpretacja strategii literackiej Hanny Krall została ujęta w inny sposób w pracy doktorskiej Anity Pluwak Ambiguous Endeavours: The Evolution of Melodramatic Mode in Polish Holocaust Narratives from Hanna Krall to the „Aftermath” (2015) ${ }^{32}$. Praca jest próbą odpowiedzi na pytanie, jakie cechy decydują o szerokim powodzeniu reportaży Hanny Krall. Analiza Anity Pluwak należy do szerokiego nurtu badań nad modernizmem, współczesnością i kulturą popularną wywodzącego się z odnowionej interpretacji pojęcia melodramatyczności przedstawionej w monografii Petera Brooksa The Melodramatic Imagination: Balzac, Henry James, Melodrama, and the Mode of Excess (1976) ${ }^{33}$ - „najbardziej wplywowej książce o literackiej melodramatyczności jako wyrazie postsakralnego stanu świadomości” ${ }^{34}$. Autorka odwołuje się również do prac, które, jak pisze, wykazały, że popularna kultura udowodniła, iż potrafi unieść problemy skomplikowane i kompleksowe, bolesne i aktualne w sposób dla nich adekwatny i że często osiąga bezpośredni efekt w postaci pozytywnej reakcji publiczności i ogólnie zwiększonego potencjału uwagi dla poruszanych problemów. Autorka wymienia przede wszystkim Andreasa Huyssena, Miriam Hansen i Lindę Williams. Zaznacza, że współcześni badacze podkreślają niespójności, paradoksy i ideologiczną ambiwalencję literackiej melodramatyczności ${ }^{35}$.

Pluwak zwraca uwagę na napięcie dające się zauważyć w wypowiedziach Krall, między z jednej strony jej przekonaniem o globalnej możliwości komunikacji o tym, że może "mówić do wszystkich”, często wyrażaną chęcią, by dotrzeć do jak najszerszej publiczności - z drugiej strony przekonaniem, że pewnych doświadczeń czy wydarzeń nie da się wytłumaczyć czy nawet ująć w słowa.

Hanna Krall często mówi o swoim poszukiwaniu środków wyrazu: „Trzeba opowiadać historie odpowiednie do stanu współczesnej świadomości”36. Melodramatyczny sposób pisania Krall opiera się przede wszystkim, według wstępnego rozpoznania, na takim wyborze środków transmisji trudnych i drastycznych

${ }^{30}$ Por. A. Jungstrand, dz. cyt., s. 274.

${ }^{31}$ K. Franzén, [recenzja z: Anna Jungstrand, Det litterära med reportaget. Om litteraritet som journalistisk strategi och etik, Lund 2013], „Samlaren” 2014, s. 265.

32 A. Pluwak, Ambiguous Endeavours: The Evolution of Melodramatic Mode in Polish Holocaust Narratives from Hanna Krall to the "Aftermath”, Lund 2015.

${ }_{33}$ P. Brooks, The Melodramatic Imagination: Balzac, Henry James, Melodrama, and the Mode of Excess, New Haven 1976.

34 A. Pluwak, dz. cyt., s. 3.

35 Tamże, s. 7-8.

36 Tamże, s. 79; za: W. Bereś, K. Janowska, Hanny Krall dowiadywanie sięswiata, „Tygodnik Powszechny”, „Kontrapunkt” 1996, nr 3, s. 1-3. 
problemów związanych z Holocaustem, by nie odstraszały i nie budziły niechęci, a opierały się na wspólnym dla wszystkich sposobie odczuwania i przeżywania - na przykład wywodzącym się z relacji rodzinnych.

Podstawowe cechy melodramatu, które Anita Pluwak śledzi w twórczości Hanny Krall, to szczególne zainteresowanie pytaniami o sposób, w jaki przeszłość oddziałuje w dalszym ciągu na teraźniejszość, jej uwaga poświęcona bohaterkom kobiecym oraz specyficzny kontakt z publicznością budowany przez kreowane, także na poziomie metaliterackim, wspólne linie wrażliwości i sympatii.

Tak więc uwaga w tej pracy skupiona jest na wysokim stopniu stylizacji i dramatyzacji reportaży Hanny Krall, nie są one zatem czytane przez Pluwak jako dokument czy literatura faktu (tak jak to robią niektórzy krytycy, na przykład Marcel Reich-Ranicki). Ta wyraźna deklaracja łączy tę pracę z postawą badawczą doktoratu Jungstrand, chociaż opiera się na innej metodzie. „Podmiotowość” (subjectivity), która znajduje się w centrum zainteresowania Jungstrand, jest traktowana w doborze narzędzi analizy Pluwak z ostrożnością. Tłumaczyć to można prawdopodobnie faktem, że ten właśnie aspekt badań Brooksa był podważany przez krytyków, którzy uważali, iż „podmiotowość” ujmowana jest w jego koncepcji anachronicznie, jako „istniejąca od zawsze" ${ }^{37}$.

Pluwak koncentruje się na sposobie obrazowania, który nazwany jest u Brooksa technique of pressure. Chodzi o zagęszczenie obrazu i rozszerzenie sugerowanego znaczenia, przede wszystkim w wyborze detalu, z którego język peryfrazy wydobywa ekstremalnie silne emocje ${ }^{38}$. Tęsknota za dramatyzacją i ukrytymi sensami leży u podstaw odpowiedzi melodramatycznej wyobraźni na świat pozbawiony sacrum $^{39}$. Hanna Krall wybiera bardzo skromne, codzienne detale, co zresztą niektórzy krytycy uważali za słabość, środki niedostatecznie silne wobec treści, które miały wyrażać; wybory te jednak były podyktowane, zdaje się uważać Pluwak, chęcią dotarcia do szerokiej publiczności.

„Obrazy przeszłości nie zaginęły i są rozpoznawane przez teraźniejszość jako dotyczące teraźniejszości”‘0. Sposób obrazowania, który powoduje, że czas przeszły jest postrzegany jako obecny w teraźniejszości, opiera się na zamiłowaniu do powtórzeń, pytań retorycznych, na rozwijaniu wątków pobocznych oraz obsesyjnym śledzeniu „znaków”, które łączyłyby wszystkie rozrzucone w czasie narracje. Cechy te oddziałują silnie na kształtowanie się perspektyw czasowych melodramatu. Pluwak powołuje się tutaj na Susan Gillman, która badała amerykański melodramat rasowy. Gillman podkreśla różnicę między

37 A. Pluwak, dz. cyt., s. 26; za: E. Hadley, Melodramatic Tactics Theatricalized Dissent in the English Marketplace, 1800-1885, Stanford 1995, s. 231.

${ }_{38}$ M. Buckley, Refugee Theatre: Melodrama and Modernity's Loss, „Theatre Journal” 2009, t. 61, nr 2, s. 181.

${ }^{39}$ A. Pluwak, dz. cyt., s. 80-81.

${ }^{40}$ Tamże, s. 81, za: S. Gillman, Blood Talk: American Race Melodrama in the Culture of the Occult, Chicago 2003, s. 204. 
romantycznym a melodramatycznym rozumieniem czasu i historii. Narracji melodramatycznej nie interesuje przyszłość i wgląd w jej tajemnicę - jest natomiast zainteresowana właśnie oddziaływaniem przeszłości na teraźniejszość. Jest to

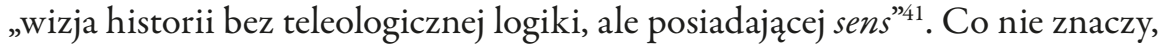
że wizja ta się sprawdza - Gillman zwraca uwagę, że sens nie zostanie odnaleziony i nie dostarczy moralnej satysfakcji w utworach, które opisują dramatyczne losy związane z ciężkimi doświadczeniami niesprawiedliwości rasowej. Charakteryzują się one otwartym zakończeniem i „odgrywają”, po raz ponowny, konflikt z przeszłości, nie rozwiązując go. Podobnie jest, stwierdza Pluwak, w utworach Hanny Krall.

Pluwak analizuje Sublokatorkę (1985) oraz Narożny dom z wieżyczka pochodzący z tomu Hipnoza (1989), który otwierała Powieść dla Hollywoodu, opisywana przez Jungstrand. Koncentruje się na motywach poszukiwania znaków i ich znaczeń, spotkań kobiet, zażyłej prywatności rodzinnej. Podnosi też motyw nigdy niekończącego się opowiadania, odczytywany nie tylko w literackim kształcie reportażu, ale także w powrotach tych samych lub podobnych wątków w utworach późniejszych. Ta otwarta forma, omawiana też w pracy Jungstrand, pozostawała według niej w zgodzie z etycznymi założeniami reportażu definiowanymi przez nią za pomocą Lévinasowskiego konceptu spotkania.

Pozycja Hanny Krall, jako dziennikarki i reportera, podobnie jak wypadku Kapuścińskiego, każe postawić pytanie o jej zaangażowanie polityczne, ideowe. Pluwak nie podejmuje obecnego w książce Jungstrand i Aare motywu cenzury jako klucza do zrozumienia formy polskich reportaży. Wzmianka o cenzurze pojawia się w tej pracy tylko jako jeden z epizodów biografii - elementów kreowanej „postaci Hanny Krall”. Autorka przytacza fragment wywiadu, w którym Hanna Krall opisywała starania o publikację swej książki $Z d q$ żý przed Panem Bogiem (1977). Pluwak przypomina, że jedna z książek Krall była wydana w drugim obiegu, który od lat siedemdziesiątych znacznie rozszerzał zakres wolności słowa w Polsce. Pisze także o związkach pisarki ze środowiskiem opozycji demokratycznej, a po jej podzieleniu się - ze środowiskiem "Gazety Wyborczej”.

Praca Pluwak pokazuje zatem, że styl reportaży Hanny Krall wynika nie tyle z problemów polskich pisarzy z cenzurą (jak sugerują to Jungstrand i Aare), ile ze świadomego wyboru strategii literackiej dopasowanej do gustów czytelników i nastawienia na dotarcie do jak najszerszej publiczności, nie tylko polskojęzycznej. Hannę Krall łączy z Kapuścińskim nie tylko umiejętność dobierania i oświetlania detalu, ale także przekonanie, o którym pisał Peter Englund, że „potrafi rozmawiać z każdym”. 


\section{Wojciech Tochman i Jacek Hugo-Bader - dysonansowe spotkania i problem wrażliwości}

W pracy doktorskiej Cecilii Aare Reportaget som berättelse. En narratologisk undersökning av reportagegenren (2021) ${ }^{42}$ pojawiają się nazwiska Hanny Krall i Ryszarda Kapuścińskiego, więcej uwagi poświęca ona jednak reportażom Wojciecha Tochmana $z$ antologii Macieja Zaremby i reportażom samego Zaremby ${ }^{43}$.

Praca ta wyraża ambicje bycia pierwszą dysertacją opisującą całościowo gatunek reportażu literackiego za pomocą warsztatu narratologicznego. Odwołuje się i częściowo polemizuje z doktoratem Jungstrand, którego zakres czasowy i tematyczny był trochę inny i w związku z tym także inne przedstawiał diagnozy i wnioski.

Zdaniem Aare podstawowym zadaniem reportażu jest pośredniczenie między czytelnikami a bohaterami; rola reportera w tekście polega na byciu „naocznym świadkiem”. Reporter jest „narzędziem” służącym „oświetlaniu” bohaterów reportażu. Autorka wprowadza pojęcie reżyserii, które pokrywa się w dużym stopniu z pojęciem autora implikowanego właściwego tekstom literackim. Przesuwa punkt ciężkości opisu reportażu i jego literackości na kwestie sposobów działań narracyjnych budujących empatię u czytelnika, realizm, mimetyzm i przede wszystkim budowanie roli reportera-świadka. Potwierdza za Jungstrand, że „dysonans" między różnymi typami reportera wprowadzonymi do tekstu, reportera „opowiadającego" $i$ „przeżywającego" oraz „dysonans” między różnymi fokalizacjami wprowadza moment wątpliwości, niepewności i świadczy o niechęci zajmowania moralnego stanowiska, co w sumie, paradoksalnie, składa się na budowanie wiarygodności reportera funkcjonującego w tekście. Jest to jedna z charakterystycznych cech reportażu modernistycznego. Cechy te, jak twierdzi, można także obserwować w reportażach szwedzkich z dwu pierwszych dziesięcioleci XXI wieku (Peter Fröberg Idling, MaciejZaremba, Nina Solomin, Martin Schibbye) ${ }^{44}$. Jej zdaniem jednak to konsonans między rolami reportera uzupełniony o wypowiedziane lub sugerowane polemiczne nastawienie jest cechą dominującą w większości reportaży literackich, nie tylko szwedzkich ${ }^{45}$.

${ }^{42}$ C. Aare, Reportaget som berättelse. En narratologisk undersökning av reportagegenren, Stockholm 2021.

43 Maciej Zaremba (dziennikarz, eseista, pisarz) pracował przez lata w „Dagens Nyheter”. W swoich książkach i seriach artykułów poruszał najbardziej aktualne tematy szwedzkiego życia politycznego i kultury, zainicjował liczne dyskusje. Zabierał głos $w$ wielu sprawach - na temat funkcjonowania służby zdrowia, wymiaru sprawiedliwości, rynku pracy, gospodarki leśnej, ewolucji szwedzkiej religijności.

${ }^{44}$ C. Aare, dz. cyt., s. 248.

45 Odpowiednio do dwóch nurtów New Journalism wyróżnionych przez Davida Easona jako Ethnographic Realism oraz Cultural Phenomenology dzieli Aare reportaż na dwa podgatunki: „modernistyczny” i „realistyczny”. Por. tamże, s. 158. 
Polskie reportaże Wojciecha Tochmana, szczególnie fragment o matce Meirze z Jakbyś kamień jadta, służy w tej pracy za przykład reportażu zbudowanego na „dysonansie”. Aare ilustruje działanie detalu, dysonansowego łączenia płaszczyzn czasowych oraz ironii z empatią w pewnych fragmentach.

O tekstach Kapuścińskiego wypowiada się Aare raczej z rezerwą. Uważa, że należą do typu reportaży, gdzie rejestrowane przeżycie własne jest podstawowym celem, a egzotyzacja współgra z budowaniem wrażenia obcości. Mijają się więc one poniekąd z podstawowymi zadaniami reportażu. Uzasadniając swoje zdanie, przywołuje liczne wypowiedzi Kapuścińskiego typu „imagologicznego”: generalizacje na temat tego, jak należy rozumieć różne grupy narodowe (na przykład przytoczony dłuższy cytat o Ormianach zaczerpnięty z Imperium ${ }^{46}$ ). Aare odrzuca interpretację Jungstrand, która przekonywała, że uogólnienia Kapuścińskiego odczytywać można w kategoriach „dysonansu”.

Praca Cecilii Aare jest osadzona w kontekście wcześniejszych prac szwedzkich na temat reportażu, dotyczących konkretnych twórców. Sama określa styl szwedzkiego reportażu jako „tradycję empatyczną”. Ważny tu jest może fakt, że jej zainteresowanie teorią poprzedzone było własną pracą reporterską - stąd może bierze się jej szczególne wyczulenie na gust czytelniczy. Gust ten ukształtowany został przez długą tradycję tekstów uwrażliwiających czytelników na sposób, jak to nazywa Aare, pośredniczenia w spotkaniu z Innym. Tutaj, wydaje się, można doszukiwać się, źródeł braku satysfakcji towarzyszącej lekturze polskich reportaży, którą widać czasem w komentarzach szwedzkich recenzentów. Podkreślają oni jednocześnie stylistyczną wirtuozerię polskich utworów i szok spowodowany tematyką reportaży, a czasem sposobem jej ujęcia.

Pisarz, dziennikarz i eseista Joar Tiberg w recenzji antologii Ouvertyr till livet („Uwertura do życia”, 2003) w „Dagens Nyheter” wybiera z niej dwa reportaże. Podobnie jak w późniejszych znacznie pracach doktorskich, wybór pada na Tochmana i na Hugo-Badera ${ }^{47}$. Reakcja jest negatywna, to właściwie czytelniczy protest. Reportaż Hugo-Badera Hiroshima, Nagasaki, Semipalatinsk Tiberg zestawia z reportażem Swietłany Aleksijewicz Bön för Tjernobyl („Modlitwa za Czarnobyl”), by pokazać, jak Aleksijewicz na długo oddaje głos swoim postaciom. „Reportaż jest jak pieśń, jest pojedynczym głosem przechodzącym przez soczewkę śmierci. Coś jednocześnie wielkiego i podniosłego. Bierze na siebie odpowiedzialność" ${ }^{48}$. W wypadku reportaży Hugo-Badera i Tochmana pojawiają się w recenzji zastrzeżenia do uprzedmiotawiającego wzroku reportera - zastrzeżenia „znane od dawna badającym teksty, ale których reporterzy nie

46 Tamże, s. 14-15. Cytaty przytoczone za: R. Kapuściński, Imperiet, tłum. A. Bodegård, Stockholm 1993, s. 103, 111.

${ }^{47} \mathrm{~J}$. Tiberg, Rafflande och tvivelaktiga polska reportage. Men vad skulle Harry Martinson egentligen ha tyckt, [recenzja z: Ouvertyr till livet, wyb., przedm. M. Zaremba, Stockholm 2003], „Dagens Nyheter", 16.12.2003.

48 Tamże. 
bardzo wydają się być świadomi”" ${ }^{9}$. Hugo-Bader przejeżdża przez dotknięte promieniowaniem obszary. „Spotyka na swej melodramatycznej drodze umierających, cierpiących głód, włącznie z psami... W tym wszystkim kilkoro ludzi"s0, którym poświęca po jednym sformułowaniu podsumowującym ich tragicznie zakończone czy zniszczone życie. Tiberg wreszcie zaczyna rozumieć: chodzi, jak głosi przedmowa, o naświetlenie przemocy systemu, który niszczy jednostkę. Jednocześnie jednak teksty te, jego zdaniem, oddychają lekceważeniem i pogardą dla tych, których portretują, ponieważ reporterom się spieszy, by opisać pogardę systemu dla jednostki.

Tiberg wypowiada się podobnie o reportażu Wojciecha Tochmana o prostytutkach z Europy Środkowej w Berlinie: „dobrze napisanym, budzącym dreszcz sensacji i głęboko wątpliwym [moralnie]" ${ }^{1}$.

Jak dostaje się Tochman do pokoju, w którym rozgrywa się scena z porwaną z Litwy dziewczyną o imieniu Birute? Jak powstała ta scena? Jakie są źródła informacji reportera? Czy w ogóle spotkał Birute? Czytelnik nie wie nic - ta niewiadoma tworzy dziurę w tekście i rośnie nieprzyjemne uczucie, że Birute jest użyta w pewnego rodzaju pół-fikcji, w głodzie sensacji, który dopełnia poniżającą scenę ${ }^{52}$.

Są też jednak w antologii reportaże, zauważa Tiberg, które odpowiadają wymaganiom reporterskiej odpowiedzialności: „En zigenare är alltid en zigenare” $(C y$ gan pozostanie zawsze cyganem) Lidii Ostałowskiej jest tekstem, który „nie jest egzaltowany i nie wymaga statystów" 53 .

Tiberg w pewnym sensie podejmuje spór z Maciejem Zarembą o przytoczony w jego wstępie cytat z Harry Martinsona (1904-1978), literackiego giganta, o którym Zaremba pisze, że uroniłby łzę, czytając o losach postaci z polskich reportaży, a Tiberg - że raczej odłożyłby tę książkę. Martinson napisał kiedyś w odniesieniu do rozrastających się sieci mediów dostarczających informacji z całego świata o globalnym „nadmiernie zapracowanym sumieniu” - o masie cierpienia, które zużywa naszą wrażliwość i wpycha w oziębłość lub sadystyczną satysfakcję $^{54}$. Tę właśnie opinię prawdopodobnie miał w pamięci Tiberg, kiedy komentował ton reportaży Hugo-Badera i Tochmana. Sceny z reportaży Tochmana i Hugo-Badera pojawiają także się w analizach Jungstrand i Aare. Ich interpretacje są jednak inne - przekonują, że reporter budzi wiarygodność właśnie dzięki dysonansom i zmianom perspektyw narracji. Rozbieżność tych ocen - znającego literaturę przedmiotu krytyka reagującego bezpośrednio na lekturę polskich tekstów

49 Tamże.

50 Tamże.

51 Tamże.

52 Tamże.

53 Tamże.

54 Komentował to Sven Delblanc, por. tenże [recenzja z: J. Wrede, Sången om Aniara. Studier i Harry Martinsons tankevärld, Akad. avh. Stockholm (Åbo) 1965], „Samlaren” 1966, s. 234. 
(2003) i badaczek podejmujących znacznie później $(2013,2021)$ ich analizę, daje na pewno materiał do refleksji.

\section{Jeszcze raz o polskim reportażu i cenzurze}

Jungstrand i Aare znają polskie tło kulturowe właściwie z drugiej ręki i nie ono jest tematem ich prac. Jungstrand wyraźnie zaznacza, że nie czuje się kompetentna, by je komentować. $Z$ tego powodu powrócić chciałabym do sprawy cenzury w komunistycznej Polsce i tezy o jej roli w kształtowaniu formy polskiego reportażu przejętej z przedmowy do antologii Macieja Zaremby z 2003 roku. Antologia przygotowana przez Zarembę była bardzo ważnym wydarzeniem, zaprezentowała serię konkretnych tekstów i określiła sposób widzenia polskiej szkoły reportażu przez szwedzką czytającą publiczność, łącznie z nową generacją badaczy gatunku. „Polska szkoła reportażu” oznacza tu formację dziennikarzy skupionych wokół „Gazety Wyborczej”, wspierającej reportaż i kształcącej nowych adeptów sztuki, utalentowanych i odważnych dziennikarzy. Przedstawiona w przedmowie opinia o korzeniach tej szkoły i o warsztacie, który powstawał jako reakcja na cenzurę, jest tylko w części słuszna - potraktować ją można raczej jako otwarte pytanie: czy tak faktycznie należy je widzieć, czy tak widzi je wielogeneracyjna formacja uprawiająca reportaż w Polsce, jeśli nawet ograniczyć polską szkołę reportażu do tej konkretnej grupy?

Konsekwencją omijania cenzury w latach komunizmu był, być może, faktycznie dobór skromnych, przyziemnych tematów w literaturze i w reportażu, sprawność w używaniu, mówiąc w skrócie, języka ezopowego oraz wrażliwość na szczegół. Jednak omijanie cenzury i dopasowywanie języka do emocji kultury popularnej może nie zawsze sprzyjało ćwiczeniu w empatii, połączonej z pogłębioną refleksją - to jest ćwiczeniu, by zawrzeć w słowie ludzkie doświadczenie. Ta obawa, nie tylko o język, ale może przede wszystkim o poziom wrażliwości ludzi, była przedmiotem troski wielu polskich pisarzy przez cały czas trwania epoki komunistycznej - najmocniej może obecna u poetów Nowej Fali, generacyjnie bliskiej „starszym” reporterom, Kapuścińskiemu i Krall. Niedokładny język, nazywany czasem radykalnie językiem „odkształconym”, był bowiem „czubkiem góry lodowej” - zdawał się mówić o tym także Englund, komentując postawy Kapuścińskiego. Były to problemy sformułowane dość dawno, ale nie są one z tego powodu anachroniczne: oprócz pytania o „nadmiernie zapracowane sumienie" (Harry Martinson), które pozostaje aktualne globalnie, może najważniejszym pytaniem dla polskiej szkoły reportażu powinno być właściwie - czy faktycznie uwolniła się ona dostatecznie od wizji świata i wrażliwości narzuconych przez język, który kiedyśs uwikłany był w omijanie cenzury? Być może tak - ale pytanie to dobrze jest od czasu do czasu postawić. Zaktualizowały go omawiane prace badaczek młodszej generacji, które w dalszym ciągu (nie wnikając skądinąd w tę problematykę) zdają się uznawać za słuszne 
wiązanie historycznych okoliczności właściwych okresowi komunizmu z cechami polskich reportaży.

\section{Bibliografia}

Aare C., Reportaget som berättelse, En narratologisk undersökning av reportagegenren, Stockholm 2021.

Bereś W., Janowska K., Hanny Krall dowiadywanie się świata, „Tygodnik Powszechny”, „Kontrapunkt” 1996, nr 3.

Bikont A., Vi frian Jedwabne, tłum. I. Grönberg, Stockholm 2014.

Brooks P., The Melodramatic Imagination: Balzac, Henry James, Melodrama, and the Mode of Excess, New Haven 1976.

Buckley M., Refugee Theatre: Melodrama and Modernity's Loss, „Theatre Journal” 2009, t. $61, \mathrm{nr} 2$.

Chatman S., Coming to Terms: The Rhetoric of Narrative in Fiction and Film, Ithaca, NY 1990.

Chatman S., Story and Discourse: Narrative Structure in Fiction and Film, IthacaLondon 1980.

Cheney Th., Writing Creative Nonfiction: How to Use Fiction Techniques to Make Your Nonfiction More Interesting, Dramatic and Vivid, Berkeley 1987-2002.

Cohn D., Transparent Minds; Narrative Modes for Presenting Consciousness in Fiction. Princeton, New Jersey 1978.

Delblanc S., [recenzja z: J. Wrede: Sangen om Aniara. Studier i Harry Martinsons tankevärld, Akad. avh. Stockholm (Åbo) 1965], „Samlaren” 1966, https:// uu.diva-portal.org/smash/get/diva2:1425102/FULLTEXT01.pdf, dostęp: 5.05.2021.

Domosławski A., Ryszard Kapuściński: A Life, tłum. A. Lloyd-Jones, London 2012.

Englund P., On Ryszard Kapuscinski, [recezja z: A. Domosławski, Ryszard Kapuściński: A Life, thum. A. Lloyd-Jones, London 2012], https://peterenglundsnyawebb.wordpress.com/2016/08/22/on-ryszard-kapuscinski/, dostęp: 12.06.2021.

Franzén K., [recenzja z: A. Jungstrand, Det litterära med reportaget. Om litteraritet som journalistisk strategi och etik, Lund 2013], „Samlaren” 2014, https://uu.diva-portal.org/smash/get/diva2:795218/FULLTEXT01.pdf, dostęp: 3.04.2021.

Gillman S., Blood Talk: American Race Melodrama in the Culture of the Occult, Chicago 2003.

Hadley E., Melodramatic Tactics Theatricalized Dissent in the English Marketplace, 1800-1885, Stanford 1995.

https://forfattarforbundet.se/forfattarforbundet-och-linneuniversitetet-i-unikt-samarbete-kring-professur-i-sakprosa/, dostęp: 15.05.2021.

Hugo-Bader J., Vit feber, thum. L. Mendoza Åsberg, Stockholm 2015.

Iser W., The Fictive and The Imaginary: Charting Literary Anthropology (1991), London 1993. 
Jungstrand A., Det litterära med reportaget. Om litteraritet som journalistisk strategi och etik, Ellerströms akademiska 41, Lund 2013, http://su.diva-portal.org/smash/get/ diva2:651856/FULLTEXT01.pdf, dostęp: 1.04.2021.

Kapuściński R., Ebenholz, Stockholm 2000.

Kapuściński R., En dag till att leva, tłum. B. Arenander, Stockholm 1987.

Kapuściński R., Fotbollskriget, tłum. A. Bodegård, Stockholm 1998.

Kapuściński R., Imperiet, tłum. A. Bodegård, Stockholm 1993.

Kapuściński R., Jeszcze dzień życia, Warszawa 2008.

Kapuściński R., Kejsaren: en envåldshärskares fal, thum. B. Arenander, Stockholm 1985.

Kapuściński R., På resa med Herodotos, thum. A. Bodegård, Stockholm 2006.

Kapuściński R., Reporters självporträtt, tłum. A. Bodegård, Stockholm 2009.

Kapuściński R., Shahernas shah, tłum. B. Arenander, Stockholm 1986.

Krall H., Hinna före Herren Gud, thum. L. Ilke, Stockholm 1982.

Melberg A., Ny litteratur passar inte in i gamla genrer, „Svenska Dagbladet” [„Under strecket"], 28.08.2008.

Ouvertyr till livet, wyb., przedm. M. Zaremba, Stockholm 2003.

Pluwak A., Ambiguous Endeavours: the Evolution of the Melodramatic Mode in Polish Holocaust Narratives from Hanna Krall to „The Aftermath", Lund Slavonic Monographs 12, Lund 2015.

Ryle J., At Play in the Bush of Ghosts: Tropical Baroque, African Reality and the Work of Ryszard Kapuścinski, „Times Literary Supplement”, 17.06.2001.

Schmidt L., Polsk litteratur är på gång i Sverige, „Svensk Bokhandel”, 27.09.2003.

Sławiński J., O dzisiejszych normach czytania (znawców), „Teksty” 1974, nr 3.

Szejnert M., Miss Boydreser till Polesien, thum. T. Håkanson, „Ord \& Bild” 2017, nr 2-3.

Tiberg J., Rafflande och tvivelaktiga polska reportage. Men vad skulle Harry Martinson egentligen ha tyckt [recenzja z: Ouvertyr till livet, wyb., przedm. M. Zaremba, Stockholm 2003], „Dagens Nyheter”, 16.12.2003.

Tochman W., Moder Mejra finner sina barn (2002), ttum. R. i E. Tornborg [w:] Ouvertyr till livet, red. M. Zaremba, Stockholm 2003.

Tønnesson J.L., Hva er sakprosa, Oslo 2008.

Zehle S., Ryszard Kapuścinski and The Borders of Documentarism: Toward Exposure without Assumption [w:] Literary Journalism Across The Globe: Journalistic Traditions and Transnational Influences, red. J.S. Bak, B. Reynolds, Massachusetts 2011. 